\title{
UPAYA MENINGKATKAN HASIL BELAJAR MATEMATIKA \\ DENGAN MENGGUNAKAN MODEL PEMBELAJARAN TGT BERBANTUAN DENGAN MEDIA TALI PAS PADA PESERTA DIDIK DI SDN 2 PETUK BUKIT TAHUN PELAJARAN 2017/2018
}

\section{Oleh : OKTAVIANI SUKA TARA*Karyanti, M.Pd}

\begin{abstract}
ABSTRAK
Penelitian ini bertujuan untuk : (1) Untuk mendeskripsikan aktivitas belajar peserta didik pada pembelajaran Matematika dengan menggunakan model pembelajaran TGT berbantuan media Tali Pas pada peserta didik kelas II di SDN 2 Petuk Bukit Tahun Pelajaran 2017/2018. (2) mengetahui peningkatan hasil belajar peserta didik pada pembelajaran Matematika dengan menggunakan model pembelajaran $T G T$ berbantuan media Tali Pas pada peserta didik kelas II di SDN 2 Petuk Bukit Tahun Pelajaran 2017/2018.

Penelitian ini dilaksanakan pada bulan Maret sampai dengan bulan Mei tahun 2018 yang berlokasi di SDN 2 Petuk Bukit, Jl Tumbang Talaken KM 86 Kecamatan Rakumpit Kota Palangka Raya. Jenis penelitian ini adalah Penelitian Tindakan Kelas (PTK) dengan subjek penelitian seluruh peserta didik kelas II SDN 2 Petuk Bukit yang berjumlah 11 orang. Teknik pengumpulan data pada penelitian ini menggunakan observasi dan tes. Penelitian ini menggunakan analisis data kualitatif dan kuantitatif.

Hasil penelitian menunjukan bahwa penggunaan model pembelajaran Teams Games Tournaments (TGT) berbantuan dengan media Tali Pas: (1) Aktivitas peserta didik selama proses pembelajaran Matematika dengan menggunakan model pembelajaran $T G T$ berbantuan dengan media Tali Paspada peserta didik di SDN 2 Petuk Bukit Tahun Pelajaran 2017/2018 berkategori sangat baik dan aktif dengan nilai rata-rata pada siklus II 3,65 ( sangat baik). (2) Ada peningkatan hasil belajar peserta didik pada pembelajaran Matematika dengan menggunakan model pembelajaran TGT berbantuan dengan media Tali Pas pada peserta didik di SDN 2 Petuk Bukit Tahun Pelajaran 2017/2018. Pada observasi mendapatkan nilai rata-rata 49,09 dengan ketuntasan klasikal 36\% meningkat pada siklus I mendapatkan nilai rata-rata 69,1 dengan ketuntasan klasikal 55\% dan lebih meningkat pada siklus II dengan mendapatkan nilai rata-rata 84,5 dengan ketuntasan klasikal 100\%.

\section{Kata Kunci : Model Pembelajaran TGT, Media Tali Pas} PENDAHULUAN

Pendidikan merupakan sesuatu yang sangat penting untuk menentukan berhasilnya tujuan

pembangunan, karena sumber daya manusia merupakan aset yang sangat berperan dalam
\end{abstract}


menggerakkan kegiatan pembangunan demi masa depan yang lebih cerah. Sebuah keniscayaan seorang manusia bisa mengelola sumber daya alam, mampu mengikuti kemajuan IPTEK, dan juga mampu ikut bersaing secara global tanpa adanya sumber daya manusia yang handal. Hal ini didukung oleh tujuan pendidikan yang tercantum dalam Undang-Undang Republik Indonesia No. 20 tahun 2003 tentang Sistem Pendidikan Nasional Pasal 1 ayat (1) yang menyatakan bahwa:

Pendidikan adalah usaha sadar dan terencana untuk mewujudkan suasana belajar dan proses pembelajaran dengan peserta didik secara aktif membangun potensi dirinya untuk memahami kekuatan spiritual keagamaan, pengendalian diri, kepribadian, kecerdasan, akhlak mulia serta keterampilan yang diperlukan dirinya, masyarakat, bangsa, dan Negara.

\section{Menurut Peraturan}

Pemerintah Nomor 19 Tahun 2005 tentang Standar Nasional Pendidikan, dinyatakan bahwa Standar Pendidikan berfungsi sebagai dasar dalam perencanaan, pelaksanaan dan pengawasan pendidikan dalam rangka mewujudkan pendidikan nasional yang bermutu yang bertujuan untuk menjamin mutu pendidikan nasional yang dapat mencerdaskan kehidupan bangsa dan membentuk watak serta peradaban bangsa yang bermartabat (Pasal 3 dan 4). Standar Nasional Pendidikan merupakan kriteria minimal tentang system pendidikan diseluruh wilayah hukum Negara Kesatuan Republik Indonesia (Pasal 1 PP No. 19 Tahun 2007) untuk meningkatkan mutu sumber daya manusia dan pengukuran kualitas pendidikan. Standar tersebut bukan merupakan ukuran yang statis yang tidak berubah, tetapi semakin lama semakin ditingkatkan. Selain itu standar pendidikan juga berfungsi sebagai pemetaan pendidikan yang bermutu.

Untuk mewujudkan tujuan pendidikan nasional tersebut harus dapat dimulai dari pendidikan sekolah. Proses belajar mengajar di sekolah memiliki guru sebagai pengajar atau pemimpin proses belajar (fasilitator) dan fungsi peserta didik sebagai pelajar atau individu belajar. Artinya bahwa seorang guru tidak hanya dituntut untuk menguasai ilmu yang diajarkan dan memiliki seperangkat pengetahuan dan keterampilan teknis mengajar, namun seorang guru juga dapat membuat peserta didik memahami konsep yang diajar maka diperlukan model pembelajaran serta media yang tepat untuk dapat menunjang dan membantu agar proses pembelajaran terjalin secara efektif dan efisien. Guru harus membantu mengarahkan peserta didik untuk mengalami 
proses pembelajaran sesuai dengan minat, bakat, potensi dan psikologinya. Oleh sebab itu, dibutuhkan sosok guru yang mampu memahami potensi dan melayani peserta didik dengan baik sehingga pembelajaran menjadi menyenangkan yang sesuai dengan kebutuhan dan karakteristiknya.

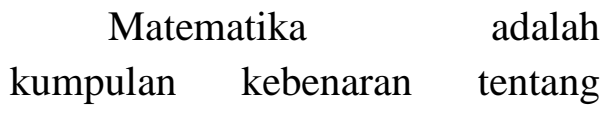
kegiatan pembangkitan masalah dan pemecahan masalah, serta kegiatan untuk menemukan dan mempelajari pola serta hubungan. Dalam pembelajaran Matematika di Sekolah Dasar, guru sangat berperan dalam meningkatkan hasil belajar peserta didik, karena pada kenyataannya pembelajaran Matematika sering dihadapkan pada masalah dimana hasil belajar peserta didik rendah terhadap materi yang dipelajari sebelumnya.

$\begin{array}{cr}\text { Akibatnya, } & \text { tujuan } \\ \text { pembelajaran } & \text { yang }\end{array}$
ditetapkan tidak dapat tercapai secara maksimal dan berpengaruh terhadap hasil belajar peserta didik. Untuk meningkatkan hasil belajar peserta didik yaitu salah satunya dengan cara pemilihan model, dan media yang tepat dalam pembelajaran. Dan penggunaan berbagai model, dan media dalam pembelajaran mempunyai peran yang besar terhadap pencapaian tujuan pembelajaran. Untuk menciptakan suasana belajar yang menarik, seorang guru membutuhkan suatu model dan media yang tepat dalam proses pembelajaran. Model dan media pembelajaran yang baik dapat membantu kegiatan pembelajaran berlangsung dengan baik, sehingga tujuan pembelajaran dapat tercapai. Kegiatan pembelajaran dapat dilakukan dengan berbagai model, dan media pembelajaran. Guru dapat memilih model, dan media pembelajaran yang sesuai dengan pelajaran yang akan dipelajari.

Berdasarkan hasil observasi yang dilakukan peneliti di kelas II SDN 2 Petuk Bukit pada tanggal 8 Januari 2018, permasalahan yang menarik yaitu kurangnya kemampuan peserta didik dalam memahami penjelasan konsep perkalian, banyak peserta didik yang masih tidak bisa mengalikan perkalian yang terdiri dari 1 atau 2 angka, saat pembelajaran matematika berlangsung banyak perserta didik yang tidak memperhatikan penjelasan dari guru. Selain itu pada setiap pembelajaran matematika tidak tersedianya media pembelajaran yang dapat memotivasi peserta didik untuk lebih aktif dalam belajar.

Hal ini terlihat dari hasil belajar peserta didik yang masih rendah, yang mana rata-ratanya masih dibawah Kriteria Ketuntasan Minimal (KKM) yang ditentukan oleh sekolah yaitu 70. Dari 11 peserta didik hanya 4 orang (36\%) yang mencapai KKM sedangkan 7 
orang lagi (64\%) belum mencapai KKM. (sumber: buku penilaian guru kelas II SDN 2 Petuk Bukit)

Hal ini juga disebabkan karena kurangnya kreativitas dalam memanfaatkan model pembelajaran dan juga media pembelajaran sebagai alat bantu mengajar, yang bertujuan untuk menarik minat, perhatian dan meningkatkan kemampuan pemahaman peserta didik dalam belajar. Dalam meningkatkan hasil belajar peserta didik diperlukan model dan media yang cocok dalam pembelajaran terutama pelajaran matematika, dengan tujuan membantu cara berpikir peserta didik untuk memperbaiki konsep pemahaman tentang materi perkalianhasil observasi bahwa kelas tersebut mempunyai permasalah. Melihat kenyataan tersebut peneliti tertarik untuk melakukan penelitian lebih lanjut mengenai "Upaya Meningkatkan Hasil Belajar Matematika Menggunakan Model Pembelajaran TGT Berbantuan dengan Media Tali PasPada Peserta Didik di SDN 2 Petuk Bukit Tahun Pelajaran 2017/2018'.Penelitian ini penting karena dengan adanya penelitian ini dapat memperbaiki proses dan kinerja pembelajaran matematika. Dengan demikian, penelitian ini juga diharapkan dapat meningkatkan aktivitas dan hasil belajar matematika peserta didik kelas II pada SDN 2 Petuk Bukit.Model pembelajaran Teams games Tournament (TGT) menurut Rusman (2014 : 224 ) menyatakan bahwa :

\section{Model pembelajaran Teams}

Games Tournament (TGT) yaitu siswa memainkan permainan dengan anggota-anggota tim lain untuk memperoleh skor dari tim mereka masing-masing. Permainan dapat disusun guru dalam bentuk kuis atau yang lainnya yang berkaitan dengan materi pembelajaran sehingga dapat mendorong keaktifan setiap siswa.

Ada beberapa langkah-langkah yang dapat dilakukan dalam model pembelajaran Teams Games Tournaments (TGT) ini antara lain sebagai berikut :

1. Penyajian kelas (Class Presentations). dalam penyajian kelas guru memperkenalkan materi pembelajaran yang diberikan secara langsung atau mendiskusikan dalam kelas. Guru dalam hal ini berperan sebagai fasilitator. Pembelajaran mengacu pada apa yang disampaikan oleh guru agar nantinya dapat membantu peserta didik dalam mengikuti games dan turnamen.

2. Belajar dalam kelompok (Teams). Peserta didik bekerja dalam kelompok yang terdiri atas 3 orang atau lebih dengan kemampuan akademik, jenis kelamin, dan ras/suku yang berbeda. Setelah guru menginformasikan materi dan tujuan pembelajaran kelompok berdisikusi dengan untuk 
memecahkan masalah bersama, saling memberikan jawaban dan mengoreksi jika ada anggota kelompok yang salah dalam menjawab.

3. Pertandingan atau lomba (Games Tournaments). Dalam permainan ini setiap peserta didik yang bersaing merupakan wakil dari kelompoknya masing-masing. Wakil kelompok yang menjawab pertanyaan dengan benar dan memakan waktu singkat akan mendapatkan point tertinggi.

4. Penghargaan kelompok (Team Recognition).

Pemberian penghargaan berdasarkan pada rerata poin yang diperoleh oleh kelompok dari permainan. Penghargaan bisa berupa poin plus atau hadiah.

Media Tali Pas menurut Tim PPPPTK Matematika (2007 : 252) menyatakan bahwa :Alat Peraga Tali Pas ini merupakan contoh alat belajar yang membimbing siswa melakukan kegiatan belajar secara mandiri. Siswa dapat mandiri melakukan proses belajar karena mereka akan menemukan apakah jawaban yang mereka buat tersebut benar atau salah dengan cara melihat jalur yang ada dibalik Tali Pas.

Langkah-langkah media pembelajaran Tali Pas adalah :

1) Guru menyediakan kartu Tali Pas yang sesuai dengan materi yang telah diajarkan.
2) Guru memberikan contoh cara penggunaaan alat kepada siswa. Kemudian, siswa diminta untuk melakuakan permainan tersebut.

3) Pengguanan Tali Pas dapat dimulai dengan bilanga perkalian yang paling mudah

4) Permainan dimulai dari atas, pada titik awal permainan yaitu dari bilangan dikali. Kemudian dicari hasilnya yang cocok pada bagian bawahnya, yaitu

5) Lanjutkan kegiatan tersebut kebagian bilangan lainnya.

6) Cari bilangan hasil yang cocok pada bagian bilangan hasil (bagian bawah) sampai semua terhubung dengan tali.

7) Setelah semua bilangan yang dikali terhubung dengan bilangan hasil (pasangannya) letakannya benang dilubang selesai dipaling pojok. Untuk meriksa hasilnya benar atau salah, baliklah kartu Tali Pas tersebut. Apabila tali-tali tersebut menutupi jalur yang ada pada bagian belakang kartu, berarti hasil perkalian itu benar.

Sedangkan menurut Rostina Sundayana (2016 : 119) menyatakan bahwa :Tali Pas adalah suatu permainan yang berguna untuk menjodohkan antara soal dann jawaban dengan menggunakan lilitan tali. Soal yang dibuat harus sesuai dengan pokok bahasan yang sedang diajarkan.Berdasarkan beberapa uraian diatas maka dapat disimpulkan bahwa model pembembelajaran Teams Games Tournaments (TGT) dan media 
Pembelajaran Tali Pas memiliki kelebihan dan kekurangan sebagai berikut :

1) Kelebihan model $T G T$

a) Tidak hanyak membuat peserta didik yang cerdas (berkemampuan akademis tinggi) lebih menonjol dalam pembelajaran, tetapi peserta didik yang berkemampuan akademik lebih rendah juga ikut aktif dan mempunyai perananan yang penting dalam kelompok.

b) Dapat menumbuhkan rasa kebersamaan dan saling menghargai sesama anggota kelompok.

c) Dapat membuat peserta didik lebih bersemangat dalam mengikuti pelajaran, karena ada hadiah yang dijanjikan oleh guru.

2) Kekurangan model $T G T$

a) Jika tidak dirancang dengan baik maka banyak waktu yang terbuang.

b) Guru dituntut untuk pandai memilih materi pelajaran yang cocok untuk model ini.

c) Guru harus mempersiapkan model ini dengan baik sebelum diterapkan.

1) Kelebihan dari media pembelajaran TaliPas yaitu siswa dapat mandiri melakukan proses belajar karena mereka akan menemukan apakah jawaban yang mereka buat tersebut benar atau salah dengan cara melihat jalur yang ada dibalik
Tali Pas. Peserta didik akan menjadi lebih aktif, berfikir dan terdapat kepuasan terhadap dirinya sendiri.

2) Kelemahan media Tali Pasadalah waktu permainan yang cukup lama karena membutuhkan konsentrasi yang ekstra. Dan jika digunakan terus menuerus akan menimbulkan kebosanan.

\section{METODE PENELITIAN}

Penelitian ini menggunakan rancangan Penelitian Tindakan Kelas atau disingkat dengan PTK. Menurut Nani Triani (2012 : 9) menyatakan bahwa :PTK merupakan salah satu stategi penyelesaian masalah yang memanfaatkan tindakan nyata dan proses pengembangan kemampuan dalam mendeteksi dan menyelesaikan maaslah, dimana proses pelaksaannya orang-orang yang terlibat dalam penelitian tersebut merumuskan tindakan atau intervensi dengan sadar, seksama dan diamati secara cermat proses pelaksaannya termasuk pada perbaikan-perbaikan yang harus dilaksanakan sampai kepada hasil akhir.Sementara menurut Kunandar (2013 : 46) menyatakan bahwa :Penelitian tindakan kelas termasuk penelitian kualitatif meskipun data yang dikumpulkan bisa saja bersifat kuantitatif, dimana uraiannya bersifat deskriptif 
dalam bentuk kata-kata, peneliti merupakan instrumen utama dalam pengumpulan data, proses sama pentingnya dengan produk.

Berdasarkan pendapat di atas dapat disimpulkan bahwa penelitian tindakan kelas atau PTK adalah suatu proses yang mengevaluasi kegiatan belajar mengajar yang dilaksanakan secara langsung dan penjabarannya bersifat kualitatif walaupun sebagian ada yang bersifat kuantitatif.

Kehadiran peneliti mutlak diperlukan karena kehadiran peneliti sangat diperlukan dalam setiap kegiatan ditempat penelitian. Peneliti berperan sebagai perencana, pelaksana tindakan, peneliti bertindak sebagai pengajar atau guru model yang bertugas membuat rancangan pelaksanaan pembelajaran (RPP) sekaligus menyampaikan bahan ajar selama pembelajaran. Di samping itu, penelitian mengumpulkan dan menganalisis data serta sebagai pelapor hasil penelitian.

Subjek penelitian dalam penelitian ini adalah peserta didik kelas II di SDN 2 Petuk Bukit untuk dijadikan sebagai sumber informasi yang dibutuhkan dalam pengumpulan data penelitian peserta didik berjumlah 11 orang yang terdiri dari 9 laki-laki dan 2 perempuan. Pengumpulan data yang diperoleh pada penelitian ini dilakukan melalui pengamatan (observasi) dan tes hasil belajar.
Penelitian ini menggunakan metode Penelitian Tindakan Kelas (PTK). Analisis data merupakan kegiatan yang dilakukan. Data yang telah dikumpulkan sebelumnya diolah menjadi dua jenis yaitu secara kualitatif dan kuantitatif. Data kualitatif diperoleh dari aktivitas peserta didik dan guru dalam proses pembelajaran dengan menganalisis keaktifan bertanya peserta didik dan keefektifan pembelajaran yang dikelola guru dengan menggunakan model pembelajaran Teams Games Tournament (TGT) berbantuan dengan media Tali Pas. Sedangkan data kuantitatif berasal dari post test yang dilakukan diakhir pertemuan. Hal ini dilakukan untuk mengetahui peningkatan hasil belajar dan keaktifan bertanya peserta didik dalam pembelajaran.

\section{HASIL PENELITIAN}

Data aktivitas guru dan peserta didik dalam pembelajaran dengan menggunakan model TGT berbantuan dengan media Tali Pas. Berdasarkan tabel di atas terlihat aktivitas guru pada siklus I diperoleh skor 3,5 meningkat menjadi skor 3,925 pada siklus II dan aktivitas peserta didik pada siklus I diperoleh skor 2,975 meningkat menjadi skor 3,65 pada siklus II. Dengan demikian data observasi aktivitas guru dan peserta didik dikategorikan sangat baik. 
Nilai Hasil Belajar, yang dimaksud ialah peningkatan hasil belajar peserta didik kelas II SDN 2 Petuk Bukit Tahun Pelajaran 2017/2018 dengan menggunakan model pembelajaran $T G T$ berbantuan dengan media Tali Pas pada materi perkalian bilangan. Hasil belajar peserta didik pada siklus I diperoleh rata-rata 69,1 meningkat menjadi rata-rata 84,5 pada siklus II. Dengan demikian data rekapitulasi nilai hasil belajar peserta didik dikategorikan sangat baik. Peningkatan aktivitas guru dan peserta didik terus mengalami perkembangan yang baik dikarenakan model pembelajaran TGT berbantuan media Tali Pas mampu membuat peserta didik menjadi lebih aktif pada saat proses pembelajaran berlangsung. Melalui model pembelajaran $T G$ dapat meningkatkan konsentrasi dan kecepatan berpikir peserta didik, peserta didik akan terbantu dalam mencari jawaban, semua peserta didik dapat terlihat aktif, kegiatan pembelajaran ini mendorong pemahaman peserta didik terhadap materi pembelajaran dengan bantuan teman-temannya satu kelompok, serta melalui media Tali Pas dapat menarik minat belajar peserta didik. Hal ini membuat peserta didik terfokus pada materi atau penjelasan dari guru.

Penelitian ini bukan untuk membandingkan antar siklus tetapi

\section{KESIMPULAN}

Berdasarkan hasil pembahasan dalam Penelitian Tindakan Kelas (PTK) yang telah dibahas maka dapat ditarik kesimpulkan sebagai beikut :

1. Aktivitas belajar peserta didik kelas II SDN 2 Petuk Bukit pada mata pelajaran Matematika dengan materi ajar perkalian bilangan, saat menggunakan model pembelajaran $T G T$ berbantuan dengan media Tali Pas Tahun Pelajaran 2017/2018 berkategori sangat baik.

2. Ada peningkatan hasil belajar peserta didik kelas II SDN 2 Petuk Bukit pada mata pelajaran Matematika dengan materi ajar perkalian bilangan, setelah menggunakan model pembelajaran TGT berbantuan dengan media Tali Pas Tahun Pelajaran 2017/2018.

\section{DAFTAR PUSTAKA}

Nani Triani. 2012. Panduan Pelaksanaan PTK. Jakarta: PT Luximametro Media

Rostina Sundayana. 2016. Media dan Alat Peraga dalam Pembelajaran Matematika. Bandung: Alfabeta

Rusman. 2014 (cetakan ke-5). Model-model Pembelajaran. Jakarta: PT Raja Grafindo Persada. 
Tunas Jurnal Pendidikan Guru Sekolah Dasar, Juni 2019, Volume 4 Nomor 2, (26-34) ISSN : 2477-6076 